\title{
Trends in Cancer Research and Chemotherapy
}

\section{Typical facial appearence of chronic GVHD}

\section{H Gozde Gul , M Ali Erkurt, Irfan Kuku and Emin Kaya*}

Inonu University, Turgut Ozal Medicine Center, Stem cell transplantation Unit, Turkey

\section{Image article}

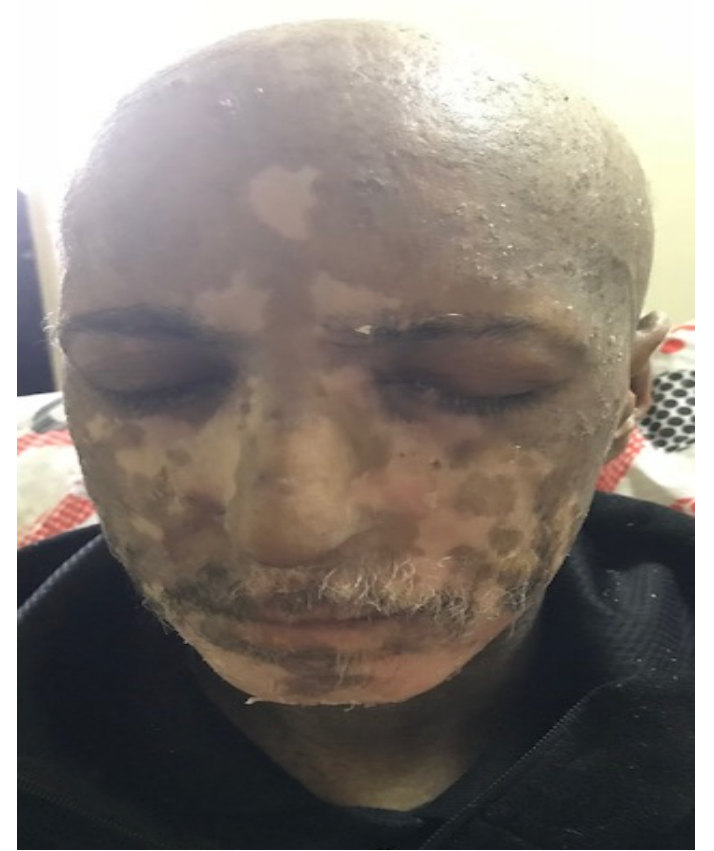

Figure 1. He has been diagnosed with AML and he has done allogenic stem cell transplantation for two years. He came up to clinic with hypopigmented and maculopapüler facial excorial lesions. He had photopheresis and ruxolitinib treatment with the chronic GVHD diagnosis

Copyright: $@ 2018 \mathrm{Gul} \mathrm{KG}$. This is an open-access article distributed under the terms of the Creative Commons Attribution License, which permits unrestricted use, distribution, and reproduction in any medium, provided the original author and source are credited.
${ }^{\star}$ Correspondence to: Emin KAYA, Inonu University, Turgut Ozal Medicine Center, Stem cell transplantation Unit, Turkey, Tel: 0422341066 / 4203; Fax: 0422 3410728; E-mail: erkurtali@hotmail.com

Received: May 21, 2018; Accepted: May 28, 2018; Published: May 30, 2018 